\title{
Working Posture Analysis for Skid Tank Gas Filling Process Using Nordic Body Map and Rapid Entire Body Assessment Method
}

\author{
Novera Elisa Triana \\ Department of Industrial Engineering, \\ Faculty of Engineering, \\ Universitas Mercu BuanaJl. \\ Raya Meruya Selatan, Kembangan, Jakarta 11650, Indonesia
}

\begin{abstract}
The objectives to be achieved in this study are to determine complaints of musculoskeletal disorders (MSDs) using the Nordic Body Map and to determine the level of risk in the operator's posture filling gas to the skid tank using the Rapid Entire Body Assessment method. The identification results using the Nordic Body Map (NBM) questionnaire showed that the most complaints felt by operators were the back. The REBA scores of this study are operator 1, operator 2, operator 3, operator 4, operator 5. Suggestion improvement as proposed on the research result is making a device in the form of a paddock that functions to place the nozzle so that the operator only has to push the device when filling the gas into the skid tank.
\end{abstract}

Key Words: Musculoskeletal Disorders, Nordic Body Map, Rapid Entire Body Assessment, Work Position.

\section{INTRODUCTION}

The application of ergonomics is critical because the lack of attention to ergonomics in the workplace can cause the risk of existing hazards. Workers are an essential asset for the company, but many companies do not pay attention to the needs and interests of workers. There are still many companies whose production process is not supported by standard methods and ergonomic work facilities, causing workers to often experience complaints about their body parts.

Operators charging gas to skid tanks often complain of aches on the back and legs. The breadth is due to receiving a reasonably heavy load every day in lifting the nozzle's heavy nozzle is $10 \mathrm{~kg}$. The complaints that arise are caused by the absence of ergonomic work facilities and by the posture of the worker to force workers to feel less comfortable.

Work comfort is one of the critical factors in the production process, by paying attention to comfort in work can reduce the occurrence of complaints at work. In industrial activities, exposure and risk in the workplace tend to exist around the workplace and workers. These conditions sometimes can not always be avoided because of work demands. Places and working conditions that are less comfortable can cause losses and even accidents. The lack of comfort and safety of working conditions is a complaint of musculoskeletal disorders [1].

The purpose of the study was to find out complaints of musculoskeletal disorders (MSDs) using the Nordic Body Map and to find out the level of posture risk of gas filling operators to skid tanks using the Rapid Entire Body Assessment method.

The problem limitation of this study is to focus on gas-charging operators to skid tanks in the field of OIL AND GAS. This research only focuses on making tool designs to help operators charge the gas to the skid tank to avoid musculoskeletal disorders.

\section{LITERATURE SURVEY}

Ergonomics (English) is derived from the Greek word ergo, which means work, and Nomos which means rules or laws. Ergonomics has various meaning limitations. In Indonesia, it is agreed that ergonomics is a science and application that seeks to disseminate work and the environment to people or vice versa to achieve the highest productivity and efficiency through optimal human use[2]. The goal of ergonomics is to increase labour productivity in a company or organization. Productivity could be achieved if there is conformity between workers and their work. Labour must be motivated and fulfilled its needs so that workers 


\section{International Journal of Engineering Research and Advanced Technology, Vol. 8, No2, February -2022}

are more enthusiastic in working so that productivity increases and decreases the number of workers who do not enter work[3]. The primary purpose of the application of ergonomics is to achieve the optimal quality of human life, both at work, in the social environment, in the family environment, and in personal life.

One of the focuses of ergonomics is posture. Ergonomic considerations related to work posture can help workers get a comfortable working posture: standing, sitting, lifting, or transporting. Work posture assessment is used to assess the risk of injury caused by errors in the handling of work materials or the non-conforming dimensions of work tools and work stations with workers' posture.[4]

\subsection{Nordic Body Map (NBM)}

Nordic Body Map (NBM) is one of the tools used to measure and recognize the source of musculoskeletal complaints. Nordic Body Map (NBM) in the form of questionnaires is often used to find out discomfort or pain in the body; respondents who fill out are asked to give signs of no disturbance in the body area. The Nordic Body Map method is a very subjective assessment method, meaning that the success of this application is very dependent on the conditions and situations experienced by workers at the time of assessment.[6], [7].

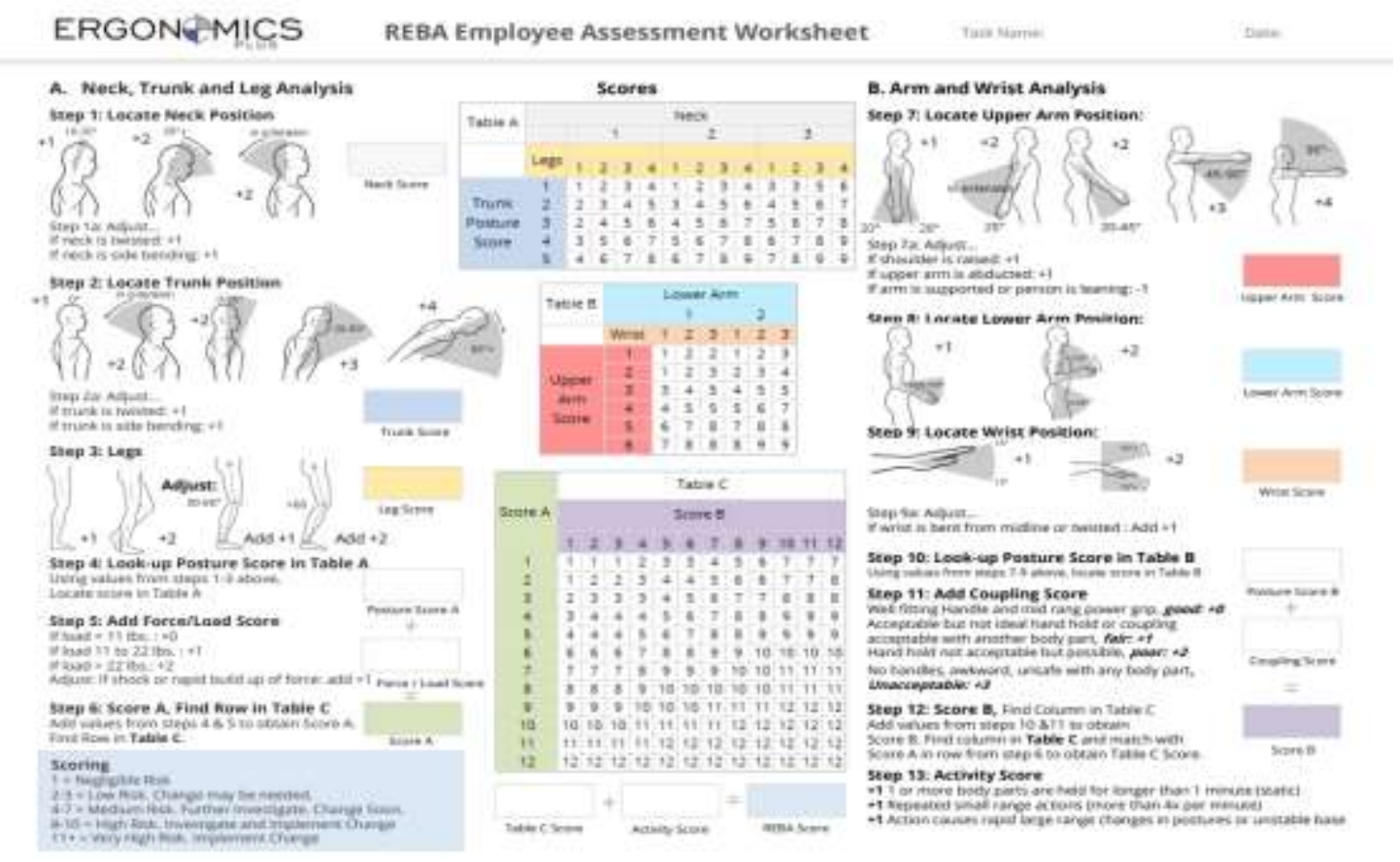

Figure 2 REBA Method Assessment Worksheet

\section{OBJECTIVE OF THE STUDY}

The main objective of this research is to identify and analyze the complaints of the operator's working position during skid tank gas filling in PT. Pertamina LPG Terminal Jakarta with the Nordic Body Map Method and the Rapid Entire Body method.

\section{RESEARCH METHODOLOGY}

The study aimed to find out complaints of musculoskeletal disorders (MSDs) using the Nordic Body Map and determine the level of posture risk of gas filling operators to skid tanks using the Rapid Entire Body Assessment method. This type of research is categorized as descriptive-analytical research because it must make systematic, factual, and accurate explanations of the facts and properties of the population based on existing data. Analytical descriptive analysis is used to understand why the phenomenon occurs.

The first stage is to identify complaints based on the Nordic Body Map (NBM). Nordic Body Map is a questionnaire in the form of a body map that contains data on body parts complained about by workers. The Nordic Body Map questionnaire is the most commonly used questionnaire to determine discomfort in workers, and this questionnaire is most often used because it is 
International Journal of Engineering Research and Advanced Technology, Vol. 8, No2, February -2022

standardized and neatly arranged. [6]

The next step is to measure the risk with the REBA method. The REBA method is used quickly to assess the posture of a worker's neck, back, arms, wrists, and legs. The steps of Reba score determination are first to calculate the score on table A consisting of neck (neck), trunk, and legs (legs). The second step counts table B, consisting of the upper arm, forearm( lower arm ), and wrist ( wrist )[7]. After getting the final score of tables A and B, then put into table C, which determines the categ ory of action.

\section{RESULT AND DISCUSSION}

Data collection is carried out by observing the gas filling operator to skid tank in the field of MIGAS business. Observations were made directly of the gas filling operator to the skid tank-measurement of working posture taken by five operators charging gas to skid tank. Identify MSDs using a Nordic body map

The percentage of complaints is calculated to find out the body parts that are more often sick in the operator's body. The Nordic body map questionnaire results recaptured the complaints that the back operator often feels. The calculation on the percentage of criticisms of the waist is as follows:

Number of operators experiencing back pain: 24 people

Number of respondents: 39 people

Table 1. Nordic Body Map Questionnaire Tabulation

\begin{tabular}{|c|c|c|c|c|c|c|c|c|c|}
\hline \multirow{2}{*}{\multicolumn{2}{|c|}{$\begin{array}{c}\text { System } \\
\text { Musculoskeletal }\end{array}$}} & \multicolumn{2}{|c|}{ Score 0} & \multicolumn{2}{|c|}{ Score 1} & \multicolumn{2}{|c|}{ Score 2} & \multicolumn{2}{|c|}{ Score 3} \\
\hline & & \multirow{2}{*}{$\begin{array}{c}\begin{array}{c}\text { Qnty } \\
(\%)\end{array} \\
0 \%\end{array}$} & \multirow{2}{*}{\begin{tabular}{|c|}
$\begin{array}{c}\text { Qnty } \\
\text { (People) }\end{array}$ \\
0 \\
\end{tabular}} & \multirow{2}{*}{$\begin{array}{l}\begin{array}{c}\text { Qnty } \\
(\%)\end{array} \\
21 \%\end{array}$} & \multirow{2}{*}{\begin{tabular}{|c|}
$\begin{array}{c}\text { Qnty } \\
\text { (People) }\end{array}$ \\
8 \\
\end{tabular}} & \multirow{2}{*}{\begin{tabular}{|c|} 
Qnty (\%) \\
$36 \%$ \\
\end{tabular}} & \multirow{2}{*}{$\begin{array}{c}\begin{array}{c}\text { Qnty } \\
\text { (People) }\end{array} \\
14\end{array}$} & \multirow{2}{*}{$\begin{array}{l}\begin{array}{c}\text { Qnty } \\
(\%)\end{array} \\
44 \%\end{array}$} & \multirow{2}{*}{$\begin{array}{c}\begin{array}{c}\text { Qnty } \\
\text { (People) }\end{array} \\
17\end{array}$} \\
\hline $\mathbf{0}$ & Upper neck & & & & & & & & \\
\hline 1 & Nape of neck & $0 \%$ & $\mathbf{0}$ & $23 \%$ & 9 & $\mathbf{5 4 \%}$ & 21 & $23 \%$ & 9 \\
\hline 2 & Left shoulder & $5 \%$ & 2 & $49 \%$ & 19 & $44 \%$ & 17 & $3 \%$ & 1 \\
\hline 3 & Right Shoulder & $10 \%$ & 4 & $4 \%$ & 19 & $36 \%$ & 14 & $\mathbf{5 \%}$ & 2 \\
\hline 4 & Left upper arm & $5 \%$ & 2 & $54 \%$ & 21 & $31 \%$ & 12 & $10 \%$ & 4 \\
\hline 5 & Back & $0 \%$ & $\mathbf{0}$ & $0 \%$ & $\mathbf{0}$ & 38\% & 15 & $62 \%$ & 24 \\
\hline 6 & Right upper arm & $10 \%$ & 4 & $49 \%$ & 19 & $33 \%$ & 13 & $8 \%$ & 3 \\
\hline 7 & Waist & $\mathbf{0 \%}$ & $\mathbf{0}$ & $3 \%$ & 1 & $38 \%$ & 15 & $59 \%$ & 23 \\
\hline 8 & Hip & $97 \%$ & 38 & $0 \%$ & 1 & $0 \%$ & $\mathbf{0}$ & $\mathbf{0 \%}$ & $\mathbf{0}$ \\
\hline 9 & Bottom & $100 \%$ & 39 & $0 \%$ & $\mathbf{0}$ & $0 \%$ & $\mathbf{0}$ & $\mathbf{0 \%}$ & $\mathbf{0}$ \\
\hline 10 & Left elbow & $56 \%$ & 22 & $36 \%$ & 14 & $8 \%$ & 3 & $\mathbf{0 \%}$ & $\mathbf{0}$ \\
\hline 11 & Right elbow & $49 \%$ & 19 & $41 \%$ & 16 & $8 \%$ & 3 & $3 \%$ & 1 \\
\hline 12 & Left lower arm & $8 \%$ & 3 & $49 \%$ & 19 & $33 \%$ & 13 & $10 \%$ & 4 \\
\hline 13 & Right lower arm & $3 \%$ & 1 & $46 \%$ & 18 & $49 \%$ & 19 & $\mathbf{3 \%}$ & 1 \\
\hline 14 & Left wrist & $0 \%$ & $\mathbf{0}$ & $44 \%$ & 17 & $46 \%$ & 18 & $10 \%$ & 4 \\
\hline 15 & Right wrist & $0 \%$ & $\mathbf{0}$ & $41 \%$ & 16 & $49 \%$ & 19 & $10 \%$ & 4 \\
\hline 16 & Left hand & $3 \%$ & 1 & $41 \%$ & 16 & $41 \%$ & 16 & $15 \%$ & 6 \\
\hline
\end{tabular}


International Journal of Engineering Research and Advanced Technology, Vol. 8, No2, February -2022

\begin{tabular}{|c|c|c|c|c|c|c|c|c|c|}
\hline 17 & Right hand & $10 \%$ & 4 & $41 \%$ & 16 & $38 \%$ & 15 & $10 \%$ & 4 \\
\hline 18 & Left thigh & $54 \%$ & 21 & $44 \%$ & 17 & $3 \%$ & 1 & $0 \%$ & 0 \\
\hline 19 & Right thigh & $56 \%$ & 22 & $33 \%$ & 13 & $10 \%$ & 4 & $0 \%$ & 0 \\
\hline 20 & Left knee & $44 \%$ & 17 & $46 \%$ & 18 & $10 \%$ & 4 & $0 \%$ & 0 \\
\hline 21 & Right knee & $31 \%$ & $12 \%$ & $54 \%$ & 21 & $15 \%$ & 6 & $0 \%$ & 0 \\
\hline 22 & Left calf & 25 & $64 \%$ & $36 \%$ & 14 & $0 \%$ & 0 & $0 \%$ & 0 \\
\hline 23 & Right calf & 23 & $59 \%$ & $36 \%$ & 14 & $5 \%$ & 2 & $0 \%$ & 0 \\
\hline 24 & Left ankle & 2 & $5 \%$ & $41 \%$ & 16 & $41 \%$ & 16 & $13 \%$ & 5 \\
\hline 25 & Right ankle & 2 & $5 \%$ & $46 \%$ & 18 & $33 \%$ & 13 & $15 \%$ & 6 \\
\hline 26 & Left leg & 2 & $5 \%$ & $41 \%$ & 16 & $38 \%$ & 15 & $15 \%$ & 6 \\
\hline 27 & Right leg & 2 & $5 \%$ & $46 \%$ & 18 & $23 \%$ & 9 & $26 \%$ & 10 \\
\hline
\end{tabular}

\subsection{Analysis Using Rapid Entire Body Assessment (REBA)}

The following data is the stage after taking body posture data on charging gas to the skid tank. Body posture data that has been created and grouped will then be given a body posture scale in the image. The posture scale data provided follows the rules of the Rapid Entire Body Assessment (REBA) method. The following are the results of the administration of posture scales on gas filling activities to skid tank.

Table 2. REBA Posture Results

\begin{tabular}{|l|c|c|c|c|c|c|}
\hline Name & $\begin{array}{c}\text { Body } \\
\text { Posture } \\
\text { Score A }\end{array}$ & $\begin{array}{c}\text { Body } \\
\text { Posture } \\
\text { Score B }\end{array}$ & $\begin{array}{c}\text { Score } \\
\text { C }\end{array}$ & $\begin{array}{c}\text { Score } \\
\text { REBA }\end{array}$ & $\begin{array}{c}\text { Category } \\
\text { Risk }\end{array}$ & Action \\
\hline Operator 1 & & & & & & \\
\hline & & 4 & 7 & 8 & High & $\begin{array}{c}\text { Immediately } \\
\text { Needed }\end{array}$ \\
\hline Operator 2 & & & & & & \\
\hline
\end{tabular}


International Journal of Engineering Research and Advanced Technology, Vol. 8, No2, February -2022

\begin{tabular}{|c|c|c|c|c|c|c|}
\hline Operator 3 & 5 & 2 & 7 & 8 & High & $\begin{array}{c}\text { Immediately } \\
\text { Needed }\end{array}$ \\
\hline Operator 4 & 6 & 2 & 8 & 9 & High & $\begin{array}{c}\text { Immediately } \\
\text { Needed }\end{array}$ \\
\hline Operator 5 & 7 & 2 & 9 & 10 & High & $\begin{array}{c}\text { Immediately } \\
\text { Needed }\end{array}$ \\
\hline
\end{tabular}

The results of Reba's calculations of all five operator activities are at a high-risk level and are needed for immediate remedial action. And if not handled immediately, there will be complaints on the body parts of the gas filling operator to the skid tank.

\subsection{Design of Work Facilities}

The results of the work posture analysis of gas filling operators to skid tanks in the field of MIGAS business obtained many working postures that pose a risk of musculoskeletal disorder injury. Based on the results of the analysis with the Nordic Body Map (NBM) questionnaire, it is known that $62 \%$ of operators have complaints on the back and based on analysis using Rapid Entire Body Assessment (REBA) that the operator's working posture has a score range of 8-10. Based on the research, the working posture of the gas filling operator to the skid tank falls into the category of high risk, so immediate repair is needed. The design of this facility aims to facilitate operators in carrying out gas-filling activities to skid tanks and reduce the level of risk. In this design, the product design principles will be used to adjust the size of the operator's body to the size of the work equipment.

\subsubsection{Spring Removal Proposal}

Moving the spring's location aims to lighten the weight when the operator lifts the nozzle from the stand when doing gas filling activities to the skid tank. 


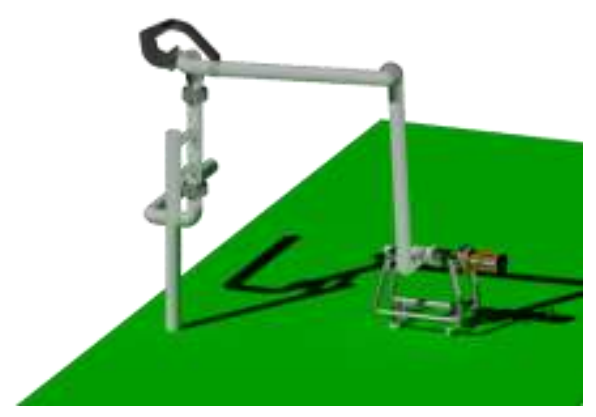

Figure 3 Spring Position

\subsubsection{Assistive Device Creation Proposal}

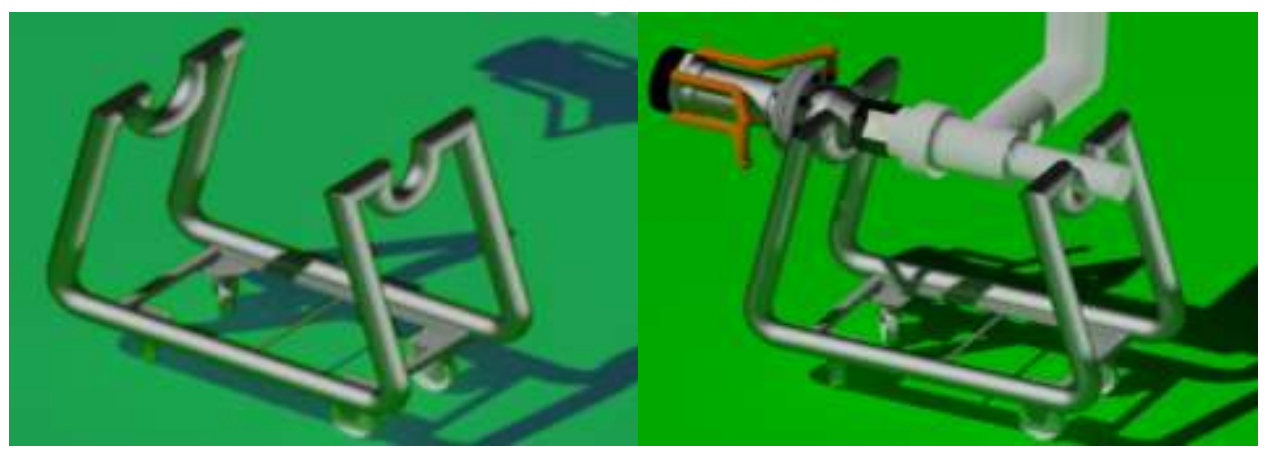

Figure 4 Assistive Proposal

The above image is a proposed tool design to help gas charging operators to skid tanks. The agency has a design similar to the paddock commonly used in motor racing events, especially MotoGP. The device's function is to support the load from the gasfilling nozzle to the skid tank to facilitate the tight op when moving the nozzle. The specifications of the device are:
a. Length: $60 \mathrm{~cm}$
b. Width: $20 \mathrm{~cm}$
c. Height: $30 \mathrm{~cm}$
d. Material: Iron Pipe and iron plate
e. Wheel: Rubber and can rotate $360^{\circ}$

\section{CONCLUSION}

Based on research conducted on gas filling operators to skid tank in the field of MIGAS business obtained the most significant percentage of complaints of musculoskeletal disorders at the level of pain score 3 (complaints of very aches and pains that are very painful in the muscles and have interfered with work) are in the back body which is $62 \%$. From the analysis of posture using the Rapid Entire Body Assessment (REBA) method, Reba scores have a high level of risk, and immediate improvement is needed.

Based on the results of the Nordic Body Map (NBM) questionnaire, several musculoskeletal complaints are included: left upper arm, right knee, left shoulder, right shoulder, right upper arm, left forearm, nape, right forearm body, right wrist, back, and waist. The complaints most widely felt by the operator charging gas to the skid tank is on the back.

Based on the analysis of working posture, the Rapid Entire Body Assessment (REBA) method has a final score in the range of 810. Based on performance standards, the final score of the work posture falls into a high category, and remedial action is required. Based on the level of risk from the operator's posture assessment results, a score of 8-10 is included in the category of immediate action required.

The proposed change in the spring's location on the nozzle pipe aims to lighten the weight of the nozzle. The difference in the spring's site affects the fulcrum of the tube connected to the nozzle, thus lightening in the operator lifting the nozzle. The proposed creation of the tool aims to make it easier for operators to move the nozzle to the skid tank so that the operator does not have to lift the nozzle too far enough to push the tool. 


\section{International Journal of Engineering Research and Advanced Technology, Vol. 8, No2, February -2022}

For the company to conduct a posture analysis of the gas filling operator to the skid tank so that the operator does not experience complaints of aches in the operator's body parts, training the operator with ergonomic and $\mathrm{K} 3$ materials and also making it easier for the gas filling operator to skid tank in lifting the nozzle so as not to affect the operator's productivity.

\section{REFERENCES}

[1] I. Yuliani and A. Z. Zhafirah, "Analisis Penilaian Postur Kerja Menggunakan Metode Nordic Body Map (Nbm), Rapid Upper Limb Assessment (Rula) dan Rapid Entire Body Assessment (Reba)," Jurnal Antara Keperawatan, vol. 4, no. 3, pp. 101-109, 2021, Accessed: Dec. 15, 2021. [Online]. Available: http://ojs.abdinusantara.ac.id/index.php/antaraperawat/article/view/640

[2] N. F. Dewi, "Identifikasi risiko ergonomi dengan metode Nordic Body Map terhadap perawat Poli RS X," Jurnal Sosial Humaniora Terapan, vol. 2, no. 2, pp. 125-134, 2020, Accessed: Oct. 05, 2021. [Online]. Available: http://journal.vokasi.ui.ac.id/index.php/jsht/article/view/90

[3] N. W. Setyanto, R. Y. Efranto, R. P. Lukodono, and A. Dirawidya, "Ergonomics analysis in the scarfing process by OWAS, NIOSH and Nordic Body Map's method at slab steel plant's division," International Journal of Innovation Research in Science, Engineering and Technology (IJIRSET), vol. 4, no. 3, pp. 1086-1093, 2015, doi: 10.15680/IJIRSET.2015.0403060.

[4] D. Kee, S. Na, and M. K. Chung, "Comparison of the ovako working posture analysis system, rapid upper limb assessment, and rapid entire body assessment based on the maximum holding times," International Journal of Industrial Ergonomics, vol. 77, 2020, Accessed: Nov. 15, 2021. [Online]. Available:

https://www.sciencedirect.com/science/article/pii/S0169814119303919

[5] J. Haekal, B. Hanum, and D. E. Prasetio, "Analysis of operator body posture packaging using Rapid entire body assessment (REBA) method: a case study of pharmaceutical company in Bogor," International Journal of Engineering Research and Advanced Technology (IJERAT), vol. 6, no. 7, pp. 27-36, 2020, Accessed: Oct. 15, 2021. [Online]. Available: https://ijerat.com/index.php/ijerat/article/view/434

[6] J. Chin, Herlina, H. Iridiastadi, L. Shu-Chiang, and S. Fadil Persada, "Workload Analysis by Using Nordic Body Map, Borg RPE and NIOSH Manual Lifting Equation Analyses: a Case Study in Sheet Metal Industry," Journal of Physics: Conference Series, vol. 1424, no. 1, p. 012047, Dec. 2019, doi: 10.1088/1742-6596/1424/1/012047.

[7] A. Juraida and A. M. Suyono, "DETERMINATION OF CRITICAL WORK STATIONS USING NORDIC BODY MAP METHOD," Palarch's Journal of Archaeology of Egypt/ Egyptology (PJAEE), vol. 17, no. 4, pp. 1372-1377, 2020, Accessed: Sep. 15, 2021. [Online]. Available: https://archives.palarch.nl/index.php/jae/article/view/4834 